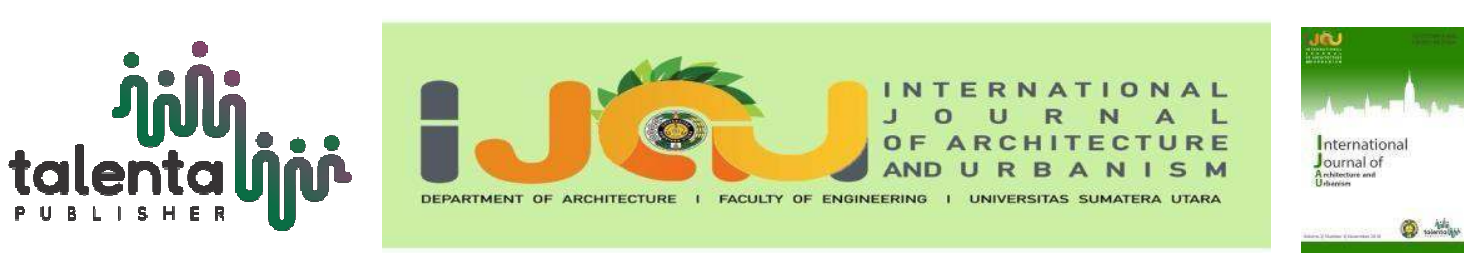

\title{
Accessibility of Public Open Space for Children with Disabilities (Case study: Gajah Wong Park And Denggung Park, D.I. Yogyakarta)
}

\author{
Andi Al-Mustagfir Syah ${ }^{1^{*}}$, Wiryono Raharjo ${ }^{1}$ \\ ${ }^{1}$ Department of Architecture, Faculty of Civil Engineering and Planning, Universitas Islam Indonesia, \\ Sleman, Yogyakarta, Indonesia
}

\begin{abstract}
A group of children experience disability in segregation conditions, namely the status of individuals who have difficulties / are denied access to public services. Many of them are marginalized and it is difficult to access existing facilities in the city. The aim of the study was to find out what application of accessibility services tended to have been implemented and which was still less applied in urban public open space planning. In terms of efforts to achieve the right of equality and fulfillment of services in the public open space for children with disabilities. The method used in this study is qualitative and this research is descriptive. By collecting data related to elephant wong parks and denggung parks. Then the data were analyzed using the Miles and Huberman analysis method, namely the analysis method with 3 stages. 1) Data reduction 2) data display 3) conclusion. The results of this study indicate that the application of accessibility services in terms of four criteria, namely: ease, usability, safety, and independence. Ease is still a priority in the design of public open space and independence is still a part that has not been well considered, so that public open space cannot be used independently for persons with disabilities.
\end{abstract}

Keyword: accessibility, open space, disabled child

\section{Introduction}

A group of children with disabilities are in a segregation condition, namely the status of individuals who have difficulties / are denied access to public services [1]. Many of them are marginalized and it is difficult to use public open spaces [2]. These problems occur because of the lack of optimal public space planning systems, especially in terms of accessibility. for persons with disabilities, accessibility services are very important because without accessibility they will experience difficulties in carrying out mobility [3].

*Corresponding author at: Universitas Islam Indonesia, Sleman, Yogyakarta

E-mail address: thagfir.mars@gmail.com 
In designing accessibility services in a equitable open city public space, there are four accessibility criteria that need to be fulfilled, namely convenience, usability, safety, and independence. To ensure alignments with persons with disabilities or users of public service facilities. Which is in accordance with the equality rights for disability regulated in the laws, policies, standards and initiatives related to persons with disabilities.

Therefore it is important to carry out various interventions in public open spaces, especially urban playgrounds that are reviewed from the four accessibility criteria, to see the application of accessibility services that tend to have been applied to public open spaces. So to review this matter, this research will be carried out in a playground environment, because the playground is a place / place for children to do various fun and activities outside their homes with their peers. Through play Children can develop social skills, learn cognitive skills, problem solving, practice motor coordination, and learn the physical world [4] [5].

The benefit of doing this research is to find out what applications of accessibility services tend to have been implemented and which are still less applied in urban public open space planning. The unclear application of accessibility services in urban public playgrounds, it will have an impact on the increasingly wide gap of failure that continues to occur in the service of urban public space users, especially children with disabilities.

The purpose of this research is to find out the application of accessibility services which tend to have been applied and which are still less applied in urban public open space planning. In terms of efforts to achieve equality rights in terms of fulfilling services in public open spaces.

The location of this study is in the first two places in Sleman Regency in Yogyakarta, because Sleman is the 35th District that received encouragement from the PPPA State Ministry to become a pilot district in terms of child-friendly city development and has launched Towards Districts that are eligible for children on July 23, 2011 [6]. And based on DIY development planning data (Bappeda DIY, 2013), Kab. Sleman is the city with the highest number of children with disabilities in the province of DIY with 864 children with disabilities, while the city of Yogyakarta is the lowest with 269 children with disabilities.

And the second location in this study was in the city of Yogyakarta which is the city with the lowest number of children with disabilities in the province of DIY. The city of Yogyakarta was chosen as the second location so that it can be seen how the application of accessibility to public 
playgrounds in cities with the lowest and highest number of disabilities in the province of DIY.

Therefore, to support cities in Indonesia to be child-friendly cities, and especially in the districts. Sleman, D.I. Yogyakarta which is expected to be a pilot city in terms of inclusive cities, this research is still very relevant to do.

\section{Literature Review}

Quoting Dewang (2010), who adapted Soetrisno's opinion, observing service facilities for persons with disabilities with the existence of technical standards regarding the provision of facilities and infrastructure related to accessibility for persons with disabilities can be adjusted to the conditions and situation of the place of placement, and the standard added or reduced, as long as accessibility principles / criteria are still well achieved,namely:

1. Convenience, that is, everyone can access and use all service facilities that are general in an environment.

2. Usability, that is, everyone must be able to use service facilities or buildings provided by the government in an environment.

3. Safety, that is, every building and open space must pay attention to safety for its users.

4. Independence, that is, anyone who is no exception to disability must be able to access and use all public open spaces or public buildings in an environment without the need for help from others.

\section{Methodology}

In this study using qualitative methods and this research is descriptive. The data collection techniques in this study are divided into two, namely primary data and secondary data. Primary data is data obtained from direct sources while secondary data is data obtained from indirect sources. Primary data includes:

1. Observations were carried out to observe the real conditions that occurred in the field and to obtain data regarding the application of accessibility in the playing area of elephant wong and the garden of the gondung.

2. Documentation is used to document field conditions related to the accessibility of public playgrounds.

While secondary data is obtained by collecting literature studies from several journals, books, and websites to obtain information related to accessibility in public playgrounds. Data that has been obtained from the results of field studies and literature studies will be managed using analytical methods. 
The method of analysis is done in three stages, namely:

\section{Data Reduction}

Data that has been obtained about playgrounds in elephant wong and parks with sleman, are summarized and selected things that are considered basic and focused on accessibility issues. So that the data can provide a clear picture and make it easier for the author to do data collection.

\section{Data Display}

After data reduction, the next step is to present the data. In qualitative methods data will be presented in several forms such as: brief descriptions, charts, tables, and the like.

\section{Conclusion}

The final step in this method is to draw conclusions. Namely the initial conclusions will be put forward are still temporary and will change if there is no evidence to support the data collection stage and if at the initial stage this is supported by valid and consistent evidence when the author returns to the field collecting data, conclusions are found is a credible conclusion.

\section{Results and Discussion}

\section{Condition of Gajah Wong Playground}

Gajah Wong Park is a public open space, where there are several facilities and infrastructure that are sufficiently complete for physical fitness needs. So that the place is always a target in the morning and evening. Because in addition to the shade and comfort of the elephant wong park, it is also equipped with various sports facilities such as jogging tracks, futsal courts, and game facilities for children. This free green open space can be used by anyone as long as the activities carried out are positive (Figure 1-3).

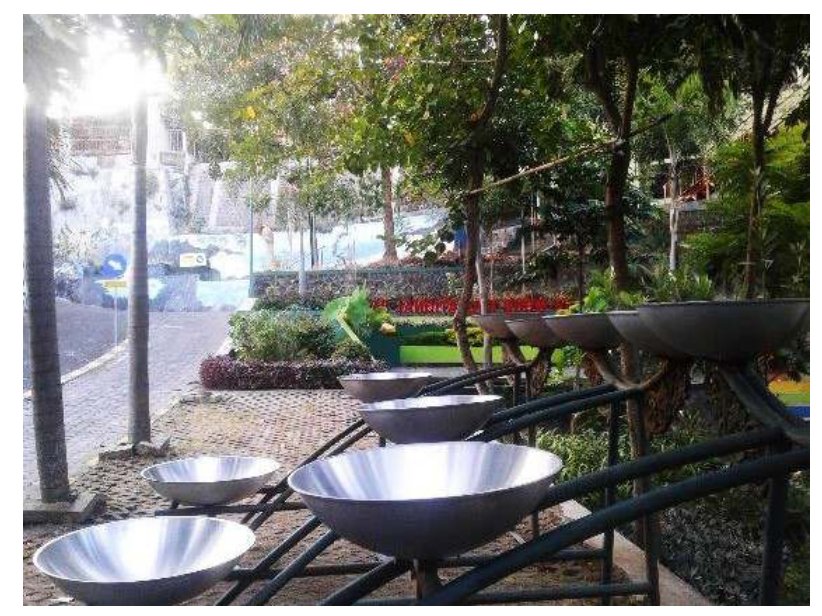

Figure 1. Pedestrian path 


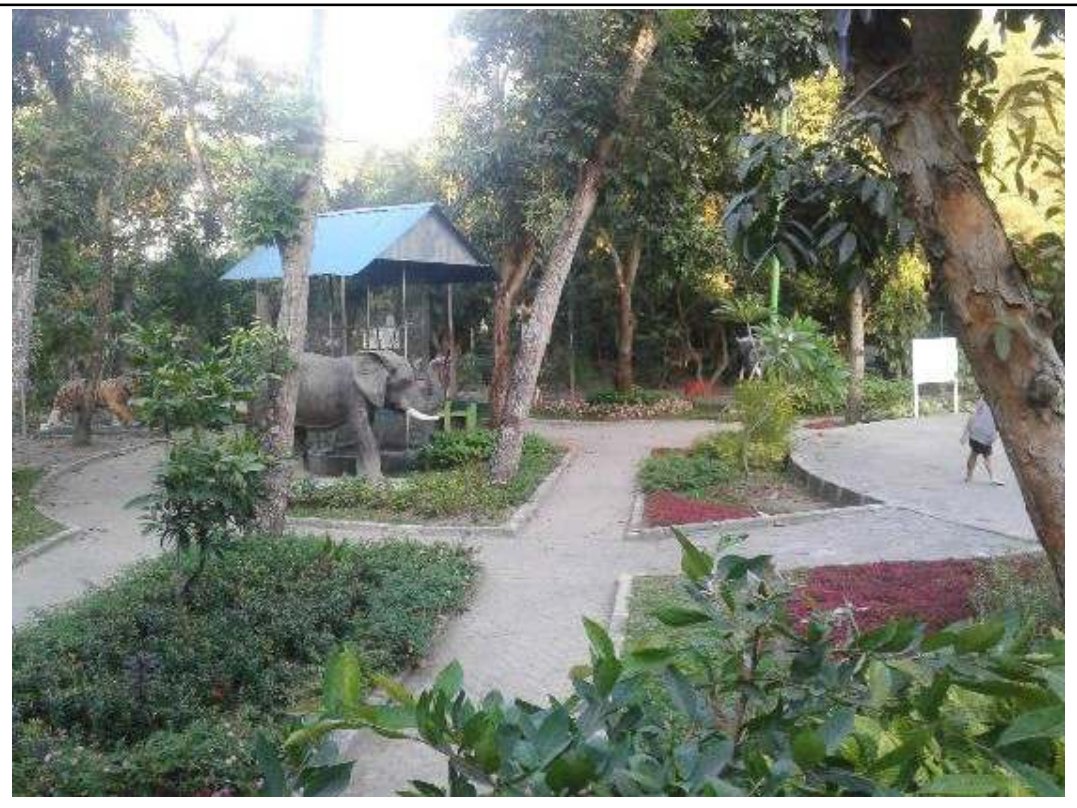

Figure 2. Jogging elephant wong park track source

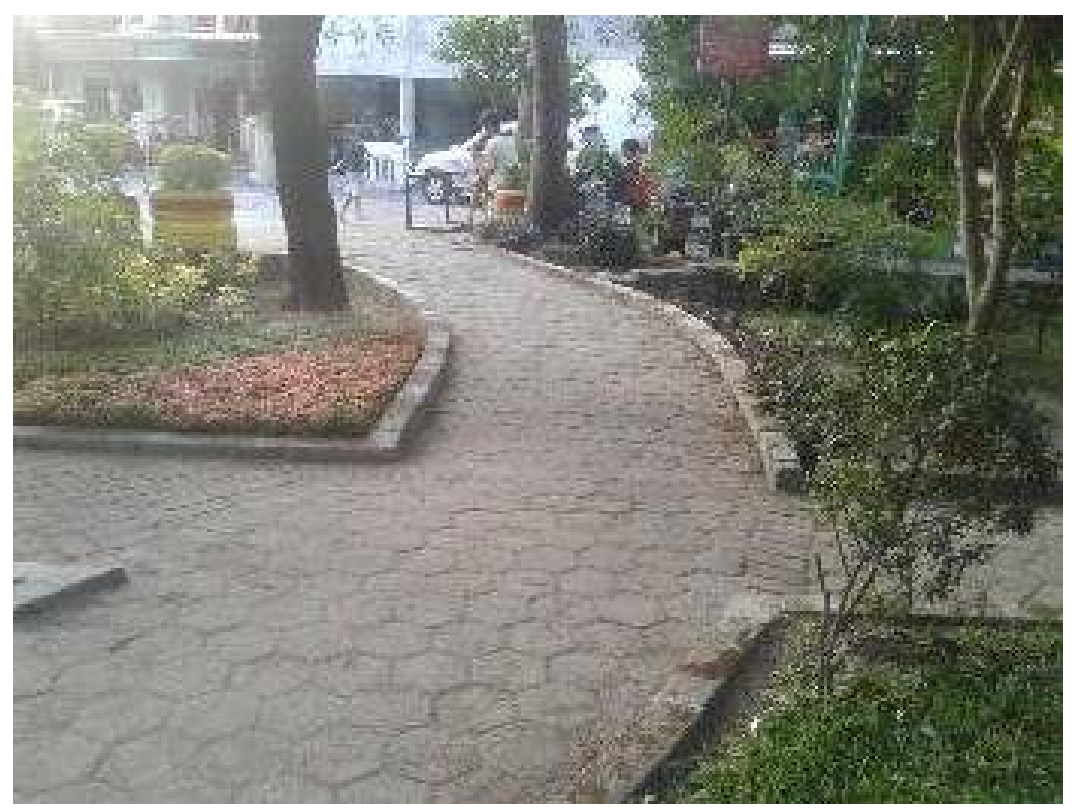

Figure 3. Ramp on jogging track source

Accessibility of the pedestrian pathway for persons with disabilities in the elephant wong park is still not accessible, there is a pedestrian lane that is provided for pedestrians, but the pedestrian lanes are made in the middle of pedestrian attributes and there are no guiding blocks that can be a marker for disability. while the jogging track is quite good with fairly flat road conditions, although there are some parts that still need to be considered for disabilities, especially blind people. And the ramp on the pedestrian lane and jogging track is quite good but the ramp is poorly maintained (Figure 4-7). 


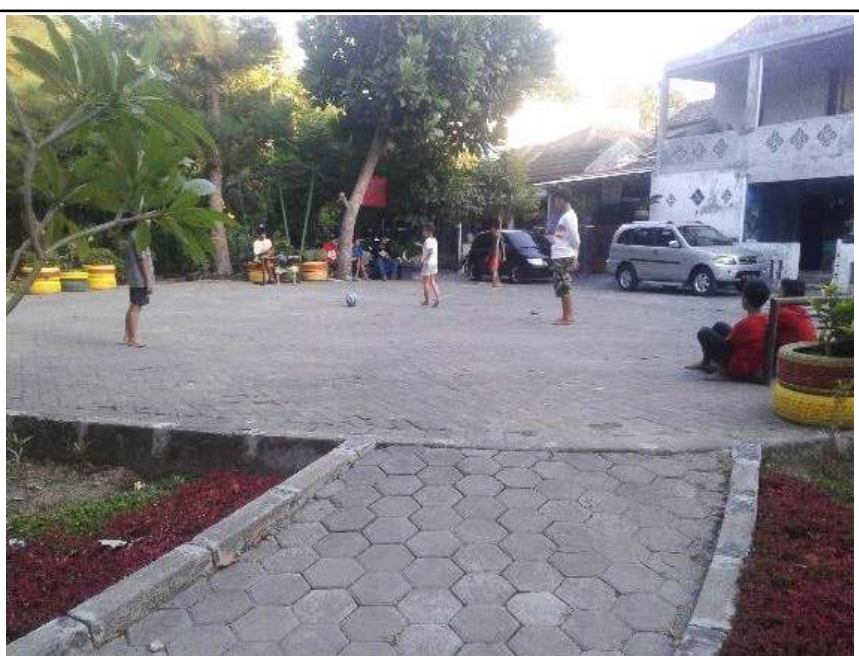

Figure 4. Futsal field Source

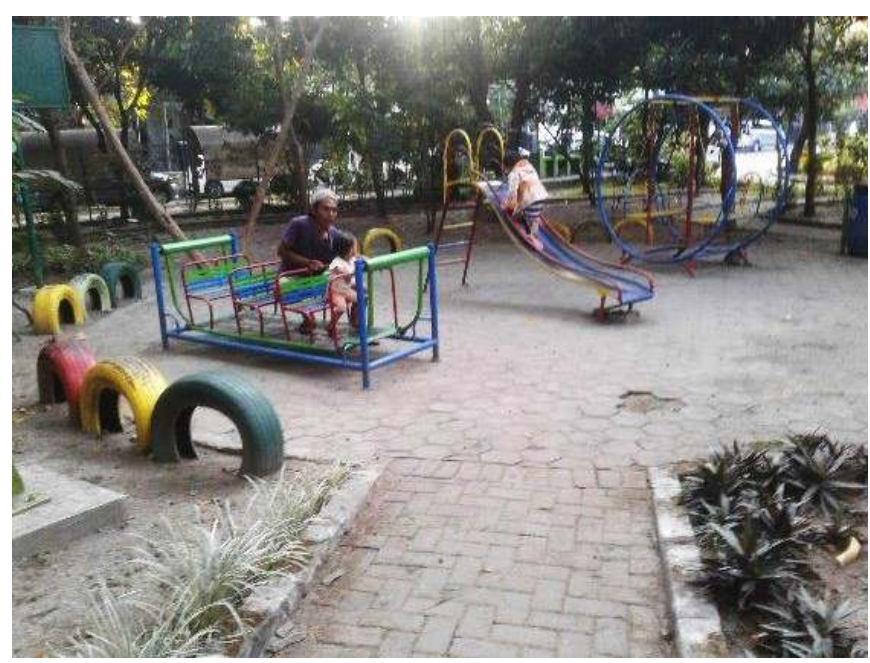

Figure 5. Game Facilities Source

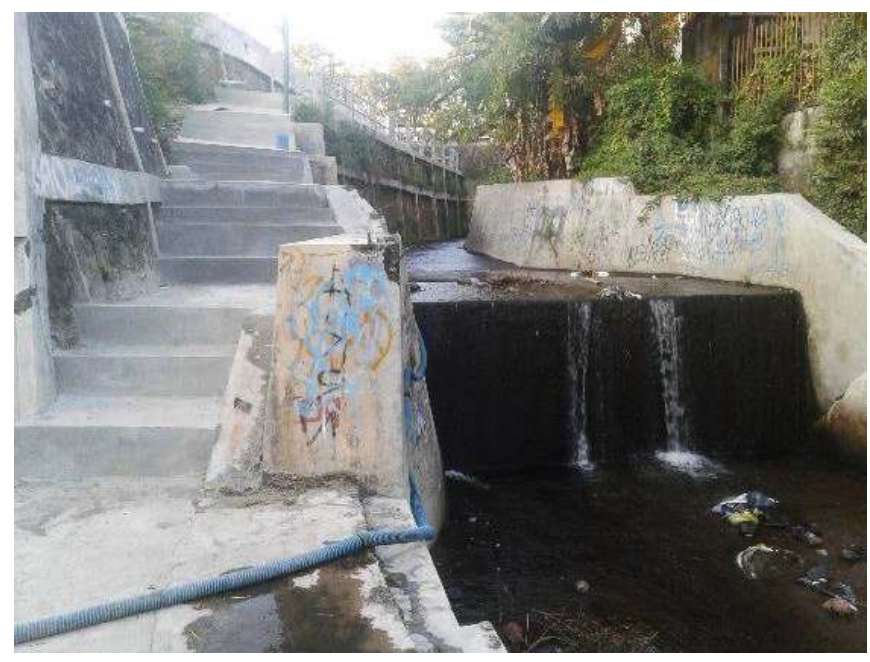

Figure 6. Fish pond Source 


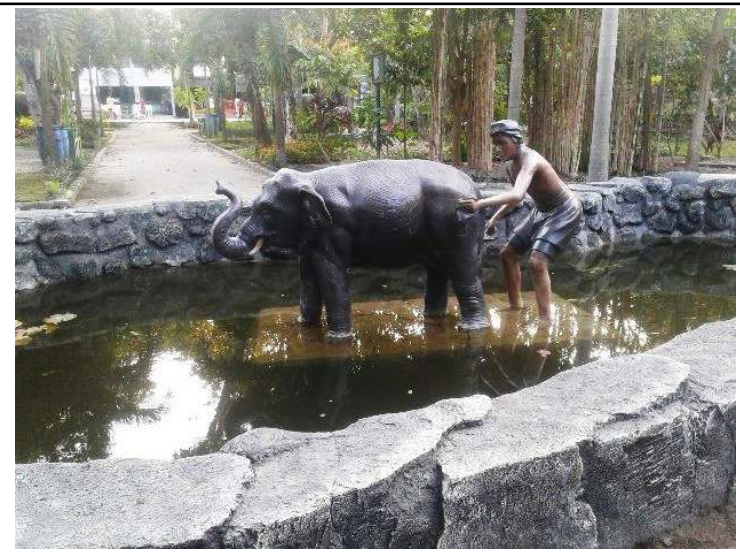

Figure 7. Fish pond Source

Supporting facilities at Gajah Wong Park are quite complete with various sports facilities, game facilities, fish ponds and other supporting facilities. but there are still many facilities that cannot be used by persons with disabilities.

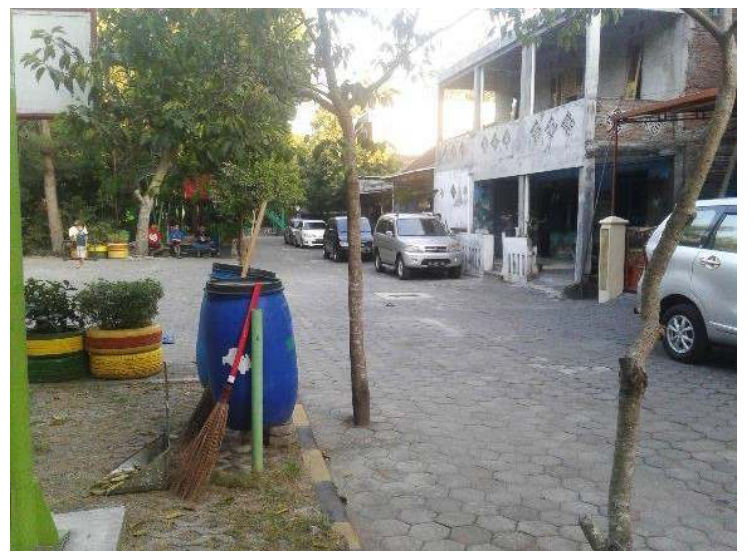

Figure 8. Parking area Source

(Private Documents, 2018)

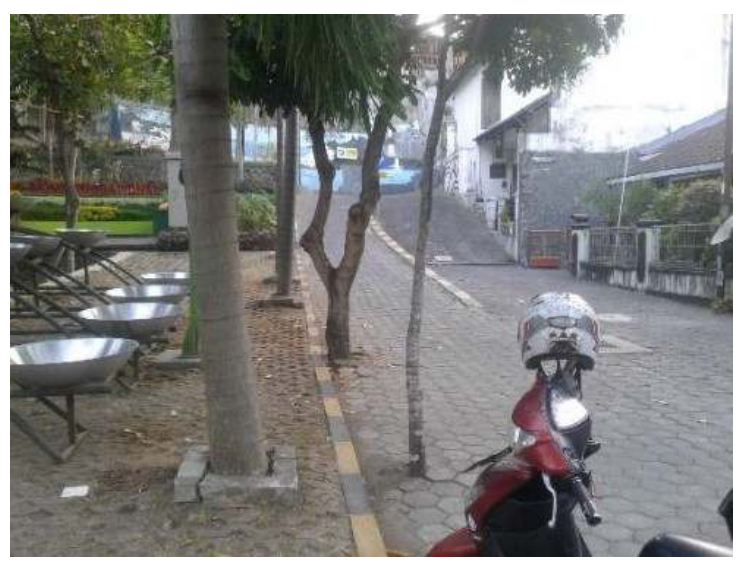

Figure 9. Vehicle circulation path Source (Private Documents, 2018) 
$\overline{\text { Gajah Wong Park has separate exit and entry lanes so that circulation of vehicles and }}$ pedestrians is more efficient. However, the parking conditions at the park are still relatively small, which can only accommodate four-wheeled vehicles with no more than 10 vehicles and two- wheeled parking lots that have not been well organized (Figure 8-9).

\subsection{Condition of Denggung Park}

The park, which stands on an area of 22,400 square meters, stores various kinds of attractive facilities for children. The park has a children's play facility that is quite complete with various types of games such as swings, prosots, globe, and many other interesting rides., in addition to increasing children's sensitivity to environmental hygiene, the trash bins in this garden are shaped like animals such as frogs and kangaroos, of course with such forms children will be more sensitive to the function of their own trash can. In addition to the game presentation provided by the manager, visitors can also find a variety of games from people who play games, such as plastic fishing ponds, mini trains, shopping, mini rickshaws to mini cars, of course this will add to the park's excitement this.

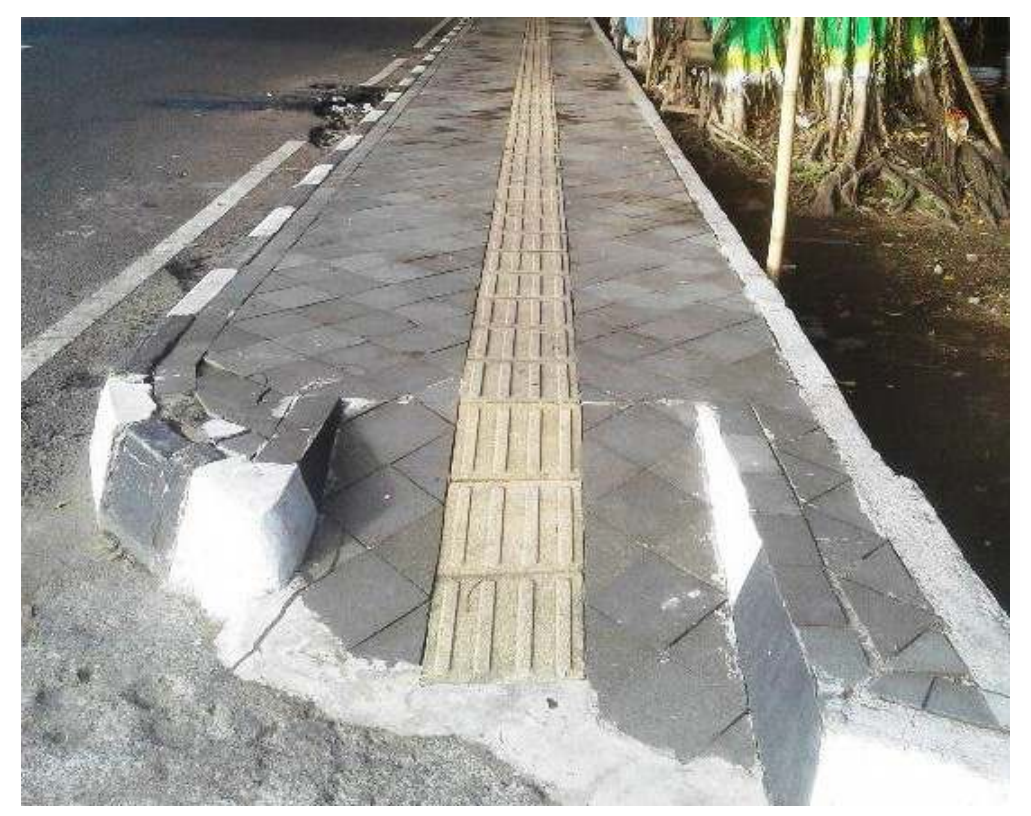

Figure 10. Pedestrian and Ramp lanes Source

(Private Documents, 2018) 


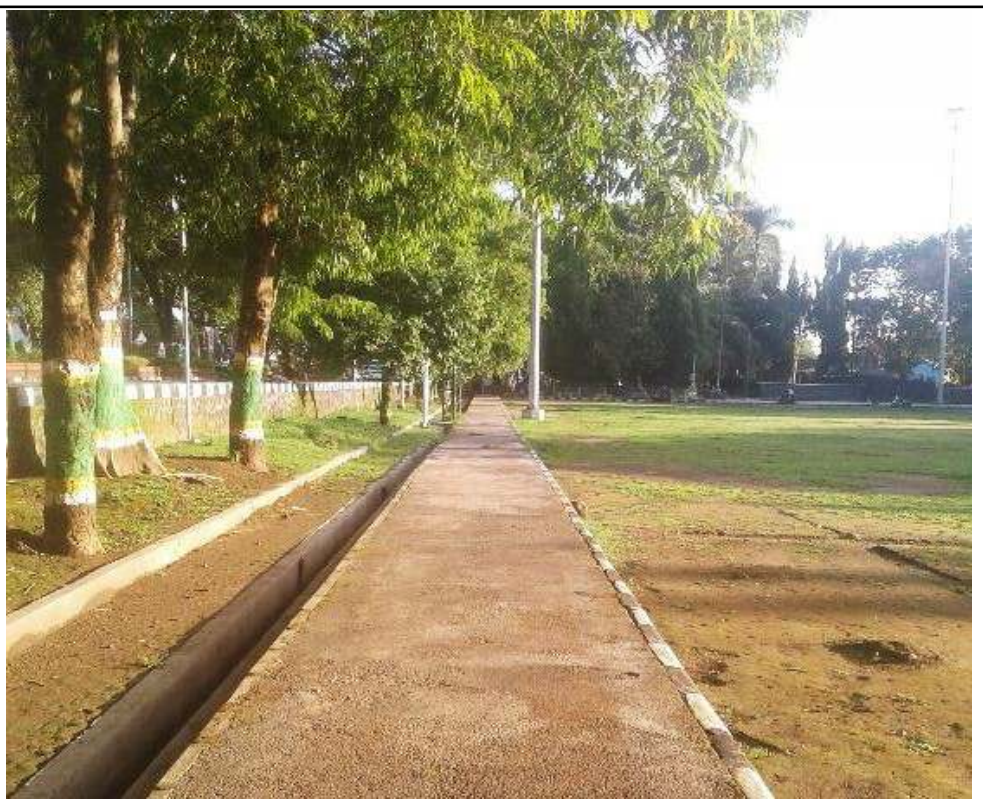

Figure 11. Jogging track Source

(Private Documents, 2018)

Accessibility of pedestrian facilities for disabled people in denggung park is still not accessible, the pedestrian lane provided for pedestrians is widely used as a trading area by street vendors, so the disabled cannot use the area. Although there are guiding blocks available for some pedestrian lines for persons with disabilities, other attributes placed on pedestrian lines are still an obstacle for persons with disabilities. while the jogging track section is quite good with fairly flat road conditions, and the ramp has been provided for disability, but it is not well maintained. (Figure 10-11).

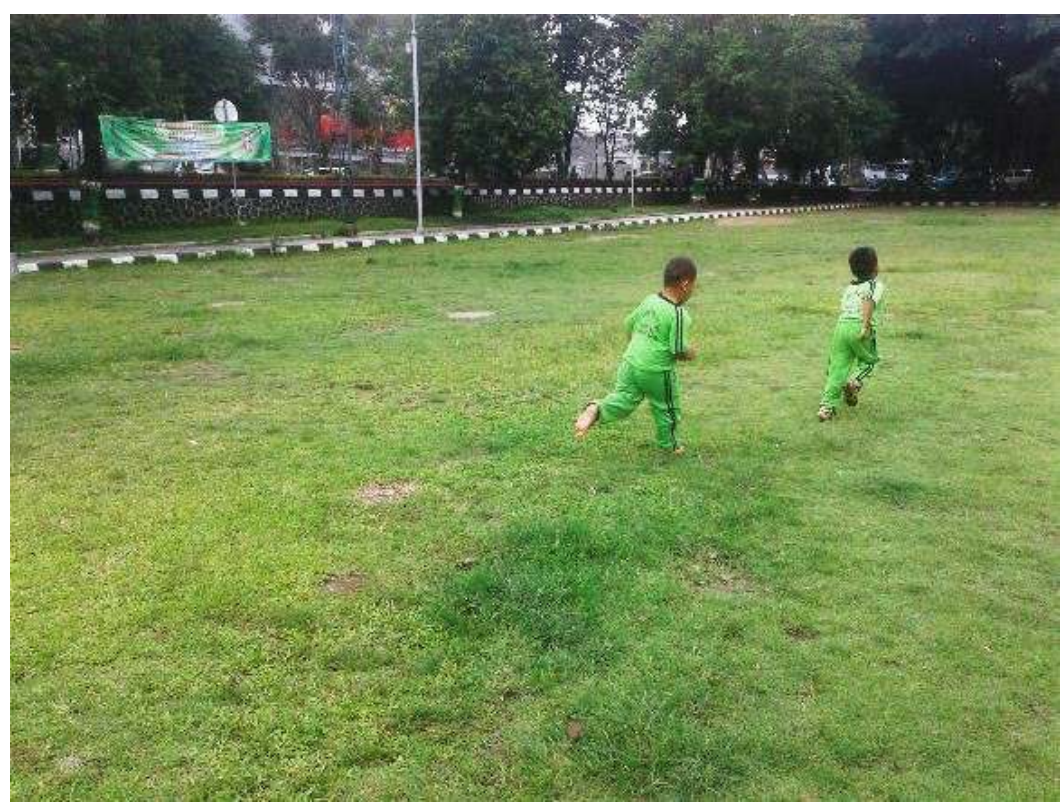

Figure 12. Pedestrian and Ramp lanes Source

(Private Documents, 2018) 


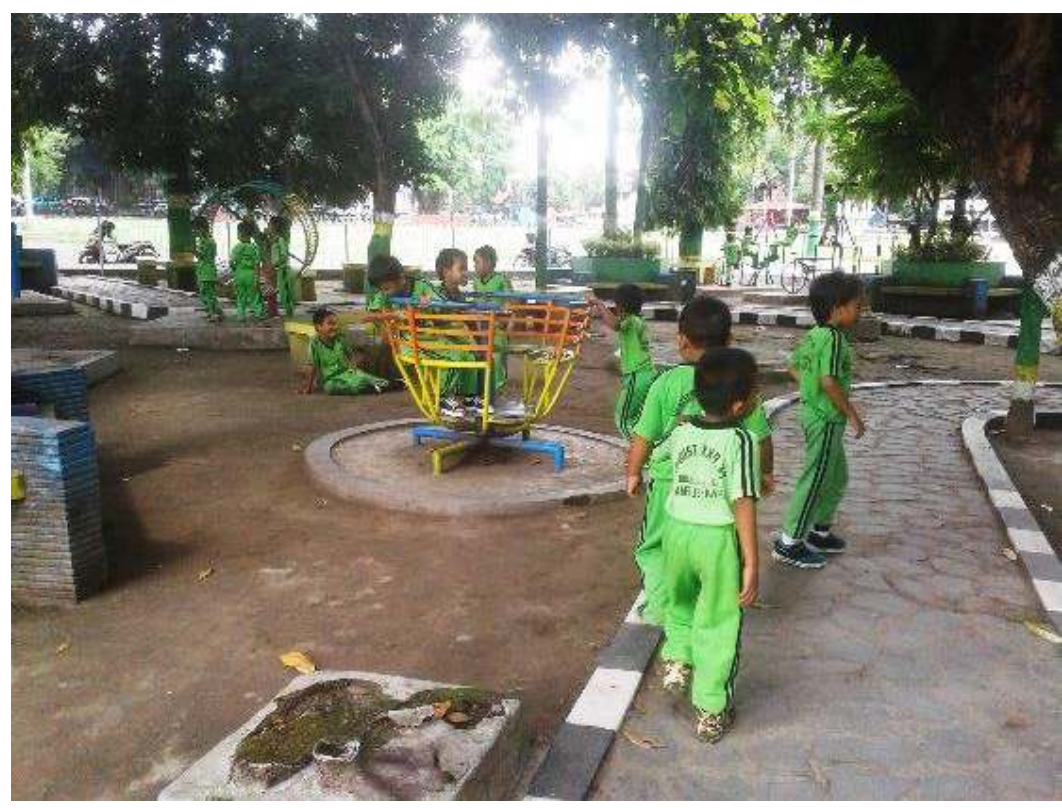

Figure 13. Pedestrian and Ramp lanes Source

(Private Documents, 2018)

Supporting facilities in the denggung park are quite complete with various sports facilities, play facilities, plazas, toilets, park benches, signs and other facilities. However, there are still many facilities that cannot be used by persons with disabilities (Figure 12-15).

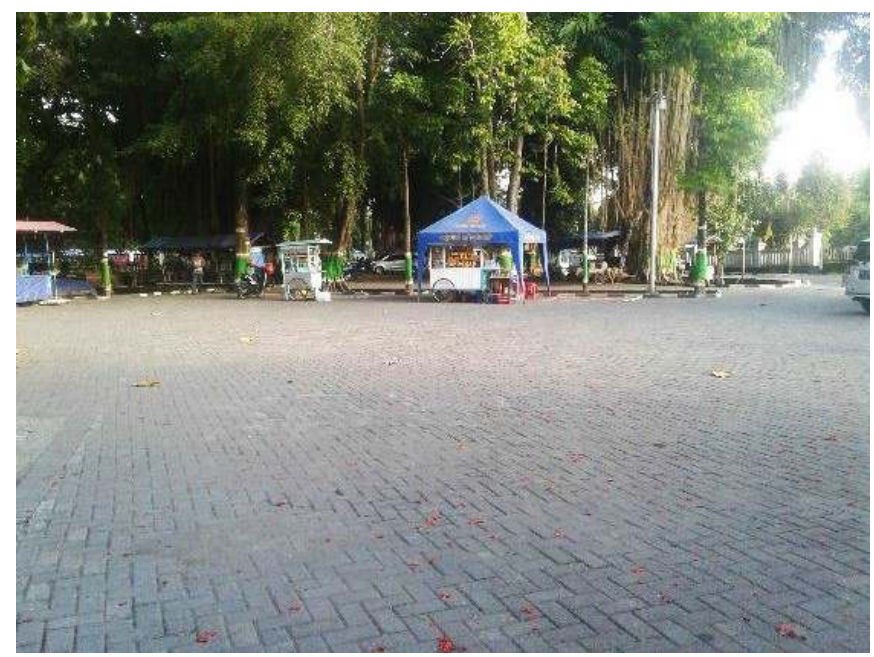

Figure 14. Parking Area source

(Private Documentation, 2018) 


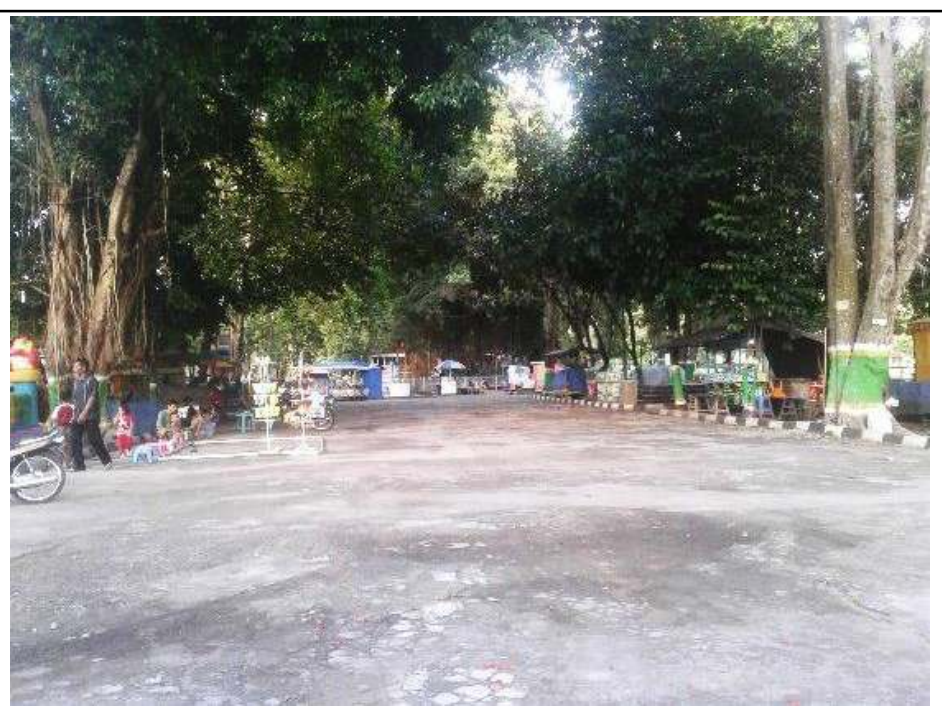

Figure 15. Vehicle Circulation Line source

(Private Documentation, 2018)

The park has a separate exit and entry lane so that the circulation of vehicles and pedestrians is more efficient. And the parking capacity is quite large so that the park can accommodate more visitors. From the results of the elaboration of the existing conditions of the elephant wong park and the denggung park, the weighting will then be carried out in terms of the four accessibility criteria, to find the application of accessibility that tends to be applied in the design of public open spaces. (Table 1 and Table 2)

Table 1. Weighting Application of Accessibility Services for Disabled Children in Gajah Wong Park

\begin{tabular}{ccccc}
\hline \multirow{2}{*}{$\begin{array}{c}\text { Facilities } \\
\text { in } \\
\text { fables }\end{array}$} & \multicolumn{4}{c}{$\begin{array}{c}\text { Accessibili } \\
\text { ty }\end{array}$} \\
\cline { 2 - 5 } $\begin{array}{c}\text { Convenienc } \\
\text { Circulatio } \\
\text { n \& } \\
\text { Parking }\end{array}$ & 1 & $\begin{array}{c}\text { Usabili } \\
\text { ty }\end{array}$ & $\begin{array}{c}\text { Safe } \\
\text { ty }\end{array}$ & $\begin{array}{c}\text { Independen } \\
\text { ce }\end{array}$ \\
\cline { 2 - 5 } & 2 & 3 & 1 & 1 \\
\hline $\begin{array}{c}\text { Pedestr } \\
\text { ian } \\
\text { path }\end{array}$ & 2 & 4 & 2 & 1 \\
\hline $\begin{array}{c}\text { Support } \\
\text { ing } \\
\text { facilities }\end{array}$ & 3 & 3 & 2 & 1 \\
\hline $\begin{array}{c}\text { Sports } \\
\text { facilities }\end{array}$ & 3 & 3 & 2 & 1 \\
\hline Signs & 1 & 2 & 1 & 1 \\
\hline Total & 10 & 15 & 8 & 5 \\
\hline $\begin{array}{c}1 \text { less } \\
4=\text { very good }\end{array}$ & & & & \\
\hline
\end{tabular}

(Source: Based on Author Research, 2018) 
Table 2. Weighting Application of Accessibility Services for Children with Disabilities in Denggung Park

\begin{tabular}{|c|c|c|c|c|}
\hline \multirow{2}{*}{$\begin{array}{l}\text { Facilities } \\
\quad \text { in } \\
\text { fables }\end{array}$} & \multicolumn{4}{|c|}{$\begin{array}{c}\text { Accessibili } \\
\text { ty }\end{array}$} \\
\hline & $\begin{array}{c}\text { Convenien } \\
\text { ce }\end{array}$ & $\begin{array}{c}\text { Usabili } \\
\text { ty }\end{array}$ & $\begin{array}{c}\text { Safe } \\
\text { ty }\end{array}$ & $\begin{array}{c}\text { Independen } \\
\text { ce }\end{array}$ \\
\hline $\begin{array}{c}\text { Circulation } \\
\& \\
\text { Parking } \\
\end{array}$ & 2 & 3 & 1 & 1 \\
\hline $\begin{array}{c}\text { Pedestrian } \\
\text { path }\end{array}$ & 3 & 4 & 2 & 1 \\
\hline $\begin{array}{l}\text { Support } \\
\text { ing } \\
\text { faciliti } \\
\text { es } \\
\end{array}$ & 3 & 3 & 2 & 1 \\
\hline $\begin{array}{c}\text { Sports } \\
\text { facilities }\end{array}$ & 2 & 3 & 2 & 1 \\
\hline Signs & 1 & 2 & 1 & 1 \\
\hline Total & 11 & 15 & 8 & 5 \\
\hline
\end{tabular}

(Source: Based on Author Research, 2018)

Based on the results of weighting the application of accessibility services in terms of the four accessibility criteria, the criteria for usability are still the most preferred point, both in the elephant wong park and in the park buzzing. while the independence criteria are still a less noticeable part, the large number of facilities available in playgrounds is still a problem for children with disabilities, because they have not been able to use existing facilities independently. Then the convenience criteria also need to be improved and taken into account again, because the many facilities that are still difficult to reach / access for children with disabilities and criteria that are no less important than the three previous criteria, namely safety, safety is a necessary point for more pay attention to every design of public open space. from the results of weighting the safety criteria are still ranked third, which means the safety criteria are still very little noticed.

\footnotetext{
*Corresponding author at: Universitas Islam Indonesia, Sleman, Yogyakarta

E-mail address: thagfir.mars@gmail.com
} 


\subsection{Proposed Plan for Providing Accessibility}

Provision of accessibility based on applicable regulations and regulations, theories, general features and problems that also exist in the needs of persons with disabilities according to their type and limitations especially for the disabled and the blind.

Accessibility of Circulation and Parking Facilities for Persons with Disabilities

Circulation

Circulation on elephant wong parks and parks with entrance and exit lanes needs to be further clarified the separation between vehicles and pedestrians.

Parking

In both parks, it must provide a special type of parking for persons with disabilities which is given in the form of signs specifically for signs as well as markers on the parking lot and ramp.

\section{Accessibility of Pedestrian Path Facilities for Persons with Disabilities}

The pedestrian pathway for persons with disabilities must be made more so that persons with disabilities can use independently and better guarantee their safety, by providing a flat, not slippery and non-terrain pathway that does not cause stagnant water.

\section{Accessibility of Activity Support Facilities for Disabled people}

For the activities of supporting facilities, the need for the design of park benches, tables, crossings, stops, toilets / restrooms, signs, and information centers that are more focused on disability needs.

\section{Conclusion}

Based on the discussion of the previous chapters, it can be concluded that, accessibility services in public open spaces are still not maximally implemented, there are several accessibility principles that still need to be improved.

\section{Elephant Wong Park}

Provision of infrastructure facilities in Gajah Wong Park is quite adequate, but the provision of service facilities in terms of accessibility is still considered less, from the assessment of four accessibility criteria, safety and independence are the most unnoticed so that the impact on disability difficulties to access and use public parks.

\section{Denggung Park}

While in the park with the provision of infrastructure facilities is very complete, but the same problem occurs, namely the principles of accessibility have not been well implemented. 


\section{Acknowledgment}

This research is an accessibility study in the public open space conducted in two public playgrounds D.I. Yogyakarta. The results of the study are intended as recommendations to the City Government of D.I. Yogyakarta to pay more attention to the right of equality in terms of accessibility in the public space, so that all city people can feel the same benefits.

\section{REFERENCES}

[1] S. M. I. Abdou, Inclusion of physically disabled children through environmental rehabilitation of urban spaces case study: AL Azhar Park, Cairo, Egypt, Procedia Eng., vol. 21, hal. 53-58, 2011.

[2] K. Widyawati, Penilaian Ruang Bermain Anak Di Kota Depok, Factor Exacta, vol. 8, no. 3, hal. 195-207, 2015.

[3] S. Thohari, Pandangan Disabilitas dan Aksesibilitas Fasilitas Publik bagi Penyandang Disabilitas di Kota Malang, Ijds, vol. 1, no. 1, hal. 27-37, 2014.

[4] M. S. Y. L. d. M. S. K. Wai, Inclusive play in urban cities : A pilot study of the inclusive playgrounds in Hong Kong, Procedia Eng., vol. 198, no. September 2016, hal. 169-175, 2017.

[5] S. L. N. e. al., Healthy play, better coping: The importance of play for the development of children in health and disease, Neurosci. Biobehav. Rev., 2018.

[6] I. K. S. F. D. U. I. d. N. U. M. I. Haq, Quo Vadis Partisipasi Masyarakat Dalam Kebijakan Kabupaten Layak Anak ( KLA ) Sleman, vol. 16, hal. 85-99, 2016. 